\title{
Security Cooperation in the Western Balkans (WB): Challenges and Opportunities
}

\author{
Anton Grizold, PhD \\ Defense Research Centre, Faculty of Social Science, University of Ljubljana \\ E-mail: is.jl-inu.vdf@dlozirg.notna \\ Marina Mitrevska, PhD \\ Ss. Cyril and Methodius University - Skopje, Faculty of Philosophy \\ Institute of Security, defense and peace \\ E-mail: marinamitrevska@yahoo.com
}

\begin{abstract}
Western Balkan thesis remains particularly popular in the circles of international politics, according to which it is necessary to emphasize the traditional situation in the countries in Southeast Europe focusing on Balkan nucleus with its immediate neighborhood. Hence, the elaboration contained herein is moving along two axes: first, an attempt is made for rational analysis of the question "Whether the Western Balkan countries have already established a system that takes care of resolving open issues and problems without using force and based on model of regional security community?" The second line of analysis refers to the experiences of the Western Balkan countries for security cooperation among them in the wider context of security and political relations in the entire Western Balkans region.
\end{abstract}

Keywords: Western Balkans, regional cooperation, security, regional security. 


\section{Securuarity}

\section{Introduction}

'South East Europe' (SEE) is usually used to emphasize the traditional situation of the countries in the SEE region focusing on the Balkan core with its near neighbourhood. In the paper, we will use the 'Western Balkans'(WB) which the EU has coined for practical reasons to encompass Albania, Bosnia and Herzegovina (BiH), Croatia, Macedonia, Kosovo ${ }^{47}$, Montenegro and Serbia. Except Albania, they were all part of former SFR Yugoslavia. In the aftermath of war the new WB countries firstly had to address the consequences of war and approach the reconciliation and peace building process, instead of embarking directly on the path of democratic and economic development. Yet, growing economic, political, security and cultural inter-dependence impacts the autonomy and functional capacities of states, and the on-going processes. Security complexity in the WB has been growing in the last 25 years due to the unfinished processes and unresolved issues based on political, socio-economic and ethno-national elements. Their interconnectedness, interplay, and mutually reinforcing impact is coupled with the fact that not all of the requirements for stability have been set so far. This results in the security framework which is becoming increasingly complex and aggravated thus challenging the functioning of the whole region and the prosperity of the entire continent.

Applying the regional approach, it is noteworthy that regionalism was a constant feature of the global security and economic architecture since WW2. Thus, regional security and regional cooperation are among the most important preconditions for peace and prosperity in the WB. ${ }^{48}$ Regional dimension will thus be given due attention as it deals with how security is clustered in a geographical region. As the security of each state in the region interacts with the security of others, this shows the intense security interdependence within a region ${ }^{49}$ and thus points to the importance of regional cooperation.

The goal of our paper is twofold: first we will briefly address the topic from the academic perspective and try to answer the following research question: HAVE THE

\footnotetext{
${ }^{47}$ Kosovo is not a member of the UN, hence the addition 'Under the UN SC Resolution 1244'.

${ }^{48}$ Ejdus, Filip (2011) Towards the Western Balkans Security Community 2.0. Analysis Faculty of Political Science, Belgrade.

${ }^{49}$ Buzan, Barry and Ole, Weaver (2003): Regions and Power.
} 
COUNTRIES OF WESTERN BALKANS ALREADY ESTABLISHED A SYSTEM that ensures the solving of open issues and problems without the use of force, based on the model of regional security community, as defined by Karl Deutsch? Second, we will address the topic from more practical aspect and, therefore, present the experiences of the WB countries of security cooperation between them in the broader context of security and political relations in the whole Western Balkan region. Hence, this paper offers a theoretical approach to the analysis of the Western Balkans. The authors will continue researching this issue through case studies e.g. Macedonia etc.

The scientific research of security paradigm at regional, national, international and global levels, during the last decade increasing attention has been paid to the regional security. The region has gained importance as a referential unit of analysis for security relations in the world. It comprises security activities and needs "beyond national state and below international system". The region thus differs from both global and national level of international community, as it represents a smaller unit than international system, and is more than just a sum of national units. In view of such a specific position of region in the international system, regional security is not analysed only as regional, but also as complex interaction between regions and other units at international and global level. In the framework of regional stability the region thus represents potential for the realization of national-security interest.

\section{New Security Architecture in the Western Balkans}

The end of the Cold War brought about a culmination of geostrategic, geopolitical, and geo-economic changes in international environment, which transformed the existing international security "architecture". Geopolitical transformations in central, eastern, and south-eastern Europe involved a dramatic turn of events triggered by the secession of former SFRJ. A diversified heritage of the Yugoslav war, based on the disruption of reciprocal contacts between states in the area, has left a difficult burden to the WB countries, which negatively impacts on their regional security cooperation. The consequences are largely seen in the stability of the region, in regional security, and indicate a difficult reestablishment of stable security relations between the WB countries. 


\section{Seccurity}

The wars on the territory of former Yugoslavia came as a surprise to both the population of this area and the entire international community which struggled for a concrete solution to this conflict. "The war in the south-east Europe warned entire Europe of the necessity to establish new European models for the implementation of certain forms of common foreign and security policy, and questioned the framework of most important European values that served as foundation for the stability, welfare, political legitimacy, and moral authority of the West from the end of the second world war until today" (Chebali and Sauerwein 1995, 179).

The establishment of political relations between the states of Western Balkans in the nineties was severely hampered by numerous armed clashes. Diplomatic relations between individual states of the region were established in the immediate aftermath of Yugoslav disintegration, while diplomatic relations between states engaged in war conflict took a while and were established later. Multilateral forums and the pressure of international community were of great importance for the development of political operation. In the aftermath of war conflicts on the territory of former Yugoslavia, political cooperation between the states was made difficult due to many open questions. To name just a few: establishment of state borders, the action of BIH brought before the International Court of Justice against Serbia and Montenegro for genocide and aggression, the unsolved question of Kosovo, and the question of adequate protection of minority rights and the rights of refugees, etc.

Regional cooperation is of utmost importance for political stability, security, and economic development of WB states. Regional stability and security is key to economic development. Through the prism of economic aspect, regional cooperation is of substantial importance for increased welfare and economic growth. With regard to the security dimension, regional cooperation contributes to the solving of key security challenges in the region, since many urgent issues, such as organized crime, corruption, illegal migrations etc., can only be efficiently tackled with A cross-border approach (European Commission, 2005).

The arguments just mentioned emphasize the key role of international support in re-establishment of cooperative relations between countries in the context of the development of regional cooperation in the Western Balkans. In recent years the main achievements in the field of cooperative relations among WB states have been the strengthening of functional and intersectoral cooperation, improvement of multilateral political relations, and improvement of bilateral political relations, although the latter 


\section{Seccurity}

constantly oscillate (Minić 2013, 34-35). Obstacles, such as economic and financial crisis, open questions in the region, fragmentation, lack of coordination, insufficient institutional capacity, and uneven development in various areas of cooperation, are still present in the process of advancement of regional cooperation in WB (Minić 2013, 35). The political will of key actors in individual regions, in particular their commitment and readiness to search for joint solutions to problems common to this area, belong to the main challenges for future development and promotion of regional cooperation. This kind of political willingness must be backed up and supported by adequate institutional, human, and financial capacities. The main problem, therefore, is located inside the political subsystem of individual states and in their intergovernmental harmonisation.

Today WB are faced with the challenge of new integration in the framework of European and Euro-Atlantic integration processes. Problems that burden the WB and present an obstacle to the EU and NATO accession (besides the aforementioned ones) are also ethnic tensions, territorial disputes, migrations, corruption, and organized crime.

Based on the analysis of two transformation processes of WB states, namely a) state-building and democratization, and b) accession to Euro-Atlantic integration, we can conclude that in the period after 2000, the WB states have made important progress towards internal political, economic, societal, and military stability, which ensures (with the help by the EU and NATO) also peace in the region. Croatia has become a member of the EU and NATO. During accession negotiations its legislation was harmonized with the European Acquis, and progress was made in the prosecution of economic crime and the protection of human rights. Macedonia and Serbia are candidate countries for EU membership and BIH, Montenegro, and Kosovo aspire to the same. Moreover, Albania has already become a NATO member state, while in June 2017 Montenegro will become a full-fledged member state.

Relations between Croatia, BIH, and Serbia have been gradually improving. Initial talks and diplomatic contacts have started between Serbia and the newly formed state of Kosovo. Bilateral relations between Croatia and Macedonia are very good, and the state of the rule of law, respect of human rights, and minority rights has been improving. Law enforcement authorities in the WB have increased their participation in the curbing of international crime. It is thus possible to say that the existing cooperation of WB states has had positive impact on regional security cooperation. However, the answer to our research question, namely whether the WB countries have 
already established a system that provides for the solving of open questions and problems on the basis of security community model and without the use of force, has to be negative. As can be seen already from a superficial analysis of the situation, reciprocal cooperation of WB states has not been developed to the level where we could confirm the existence of the regional security community as defined by Karl Deutsch and other international security scholars (e.g. Adler, Barnett, Atina, and others). Therefore, the following common elements of the regional security community theoretical model are singled out. Namely:

- The highest level of security cooperation is institutionalised

- The absence of conflict behaviour or provision of high level of peace and security

- Security relates to all areas of human existence in the society, not only to the military

- Security is formed in response to various internal and external interactions of entities in the region

- A sense of community and common identity in the region is created.

In the case of WB, it is difficult to speak of the creation of a regional security community according to the given criteria, since the endeavours of countries in the region are mostly invested in the EU and NATO membership, and not in the establishment of their own regional security organization. EU and NATO, which operate in a much broader political and territorial context, already have great impact on the WB states. There seems to be some overlapping or strong impact of transregional security organization. It is thus possible that a real security community (as for example the Nordic or Euro-Atlantic) will not be developed in the WB region, for there will be no need for it.

\section{Western Balkan Region: GEOGRAPHY AND PLAYERS}

Let us now turn to the second part of our analysis, where we will consider some practical aspects of current security situation in WB and implications for future development of regional security cooperation.

There is a well-known saying "tell me where you are from and I will tell you what your problems are". 


\section{Seccurity}

Geography to a large extend determines policy. Looking at the map, the region of WB is both blessed and cursed by being at the crossroads of trade and influences coming from all directions. Living in this transit region brings us multiple advantages as well as more than our fair share of security challenges.

In the context of the current geopolitical situation the Balkans is still used as a playground for big powers. From the East, Moscow continues to try to exert its influence through its grip on the energy sector and through historical alliances with Orthodox nations. From the West, in particular from its most influential capital Berlin, conditional carrot is being offered in the form of Euro-Atlantic integrations. For Berlin, this is about bringing the region closer to the EU and, eventually, to EU membership, bringing long-term stability to the Western Balkans, and, of course, ensuring German economic interests in this part of Europe.

In 2013, Serbia signed a military cooperation agreement with Russia. And in October 2014, much to Berlin's chagrin, Serbia rolled out the red carpet for Putin, with president Nikolić awarding him the country's highest order. Russia has also long been a staunch supporter of the Republika Srpska, and there are rumours that Moscow is inquiring about a possibility to establish a navy base in Montenegro. On the other hand, a few years ago we saw our heads of government being summoned to Berlin on a short notice to discuss Euro-Atlantic perspectives of the WB and various (mostly infrastructure) projects which could be financed from the EU budget.

However, a few years ago EU has a lot of pressing issues (and Russia even more), hence the European Commission President Jean-Claude Juncker has put the Western Balkans way down on his agenda.

The WB is seen as one of the European regions most vulnerable to Islamic terrorism, due to its transit character and radicalisation of minor parts of Muslim populations. Experts note that the region may play a secondary role in terrorist plans, as a transit point for terrorists, and a place for rest and recuperation. Moreover, they agree that the region's persisting problems continue to make it vulnerable to terrorist groups in the future. We should also be aware of the issue of so-called foreign fighters returning from the MENA region (Middle East and North Africa).

Last but certainly not least is the issue of organized crime. Each of the Western Balkans states is faced with security threats of trans-national nature, such as organized crime, arms, drugs and human trafficking, corruption, illegal migration, money laundering. These activities are facilitated by poor law enforcement and 


\section{Securiagues}

insufficient prevention through joint regional efforts. The necessary measures to tackle these threats are in place but they are not always implemented. This is due to the weakened state institutions, political and criminal interests and the lack of human and financial resources. Advancement in the fight against organized crime, political extremism and radical structures is crucial in order for the Balkans to achieve long term security and stability.

\section{ASSESSMENT OF DEFENCE COOPERATION AMONG WB COUNTRIES TO DATE}

When discussing defence cooperation in the Western Balkans, we will try to answer a couple of questions. The first (one) addresses the current state of Western Balkans in the area of security cooperation.

Since even before the end of armed conflicts of the 1990s, we have acquired quite a few frameworks for regional defence cooperation: South-Eastern Europe Defence Ministerial (SEDM), Regional Arms Control Verification and Implementation Assistance Centre (RACVIAC), South-Eastern Europe Clearinghouse (SEEC), SouthEastern European Cooperation Initiative (SECI), Adriatic Charter ( $A-5)$. When Slovenia tried to rationalize some of these initiatives in September 2013, we managed to create one more defence cooperation framework called Comprehensive Regional Ministerial (CRM).

In a decade and a half since the last large scale conflict in the region we have had plenty of meetings on various levels, exchange views and best practices. At first, these meetings were important simply because they did take place and were seen as a trust building measure by third countries that (partly) financed these initiatives.

However, despite the needs and external financial and moral support for regional security cooperation in the Western Balkans, real progress is lacking. To some extent the reason is that regional security cooperation was perceived as a means to an end, as a transitional tool to facilitate Euro-Atlantic integrations of each state in the region. Governments were committed only by declaration, with few resources and experts provided, and few practical measures undertaken between any two high-level meetings. 
More or less the same can be said for bilateral cooperation in the WB Region. We do not venture further than briefings about national (lack of) defence capability development, ways and sideways of defence reforms.

Few concrete defence cooperation programmes, such as Balkan Medical Task Force, take numerous meetings and many years to emerge from the drawing board. And even then, the creation of task force is painfully slow and it may take many more years before it becomes operational, let alone deployed in operation. To be fair, we also have to mention successful Croatian initiative for A-5 cooperation in military police school in Kabul.

After so many mostly wasted years it is high time for us to move forward under our own steam.

To sum up, we are definitely not lacking tools for regional defence cooperation. What we are lacking is political will and public support to give substance to our security cooperation.

\section{A BOTTOM-UP APPROACH}

The next questions to be asked are the following: Which are the most pressing security threats WB Region is facing? How can we address them together? Can we get both public and political support to devise regional response and implement it?

First of all, security is a much broader term than defence. The security challenges our region is facing are by no means only military in nature. On the contrary, in fact, I believe that there is only a remote possibility of a large scale military conflict in the foreseeable future.

What we could therefore suggest is a kind of bottom-up approach. Given our complex history, defence cooperation may be a non-starter. We should instead focus on those areas of cooperation where we have already made substantial headway in the past. Even without foreign encouragement. Enhanced cooperation between police forces of WB countries is the first obvious choice. Disaster protection/mitigation and rescue is the second one. The first carries less political connotations, the second none whatsoever. We do much better when politics is not involved. Mutual benefits for all parties concerned are obvious, hence public and political support should be forthcoming. These two suggested field of cooperation could prove to be excellent 
confidence builders. From there we should proceed to defence cooperation on a stepby-step basis.

One of the most pressing security threats to the Balkans is emerging from the side effects of conflicts and failing states in the Middle East and Northern Africa: refugees fleeing to Europe, increase in drugs, arms and human trafficking. Many of refugees and smuggling routes are leading through the Balkans. Minimizing security threats emanating from these illegal activities is clearly in our common interest.

Although natural and man-made disasters do not come to most experts' minds when talking about security challenges, they may turn out to be the most convenient ice breakers in the Western Balkans security cooperation. Due to climate change, which makes our weather ever more unpredictable and extreme. The number and scale of climate-related disasters is unfortunately likely to increase. Our region is prone to floods, landslides, heavy snowfall, forest fires, and in some areas, ought. And what is more natural than helping your neighbour in need? This is not only the right thing to do, it also creates gratitude, a deep bond and, as a result, trust. In our view, enhanced cooperation in strengthening disaster preparedness and facilitating disaster relief will also pay political dividends. Furthermore, it might be a game changer in the culture of post 1990s cooperation in the Western Balkans. Slovenians were touched by suffering inflicted upon Serbian population in the 2014 floods and overwhelmed by genuine gratitude that our help generated.

The most obvious security challenges are ethnical tensions that seem to be rather swept under the carpet than extinguished. There are many unresolved issues that can be used by internal or external actors in the current regional and broader geopolitical situation. We do not foresee this could result in major conflicts, but even minor incidents (for example the Infamous football match in Belgrade) can have unforeseen consequences. We think these challenges should not be viewed as security but as political issues. The solution can only be a political one. However, it can be addressed indirectly by enhancing cooperation on other security related issues, such as fighting against organized crime and helping each other in disaster relief efforts. 


\section{Securuarity}

\section{CONCLUSION}

To conclude, our goal for, let us say, the year 2025, should be excellent cooperation in disaster relief \& rescue and good police and law enforcement cooperation. These efforts will significantly contribute not only to a safer environment for our populations but also to the enhancement of trust, which is an essential precondition for any meaningful defence cooperation. One could firmly believe that the hardest nut, that is, the unresolved issues emanating from ethnical tensions, will be cracked by political means on the basis of bottom up security cooperation.

One cannot be sure about the exact year that this goal will be reached, some issues need a longer time to mature properly here in the Balkans. However, the lessons learned of our analysis prove that the countries of the WB can work together.

We need to learn again to work together, not because this is suggested or even demanded by preachers of the Euro-Atlantic integrations gospel, but because we will be safer and better off if we overcome the troubled past and provide our children and grandchildren with a good example of how security cooperation is well worth it while.

In particular, preservation of peace and stability, regional cooperation and EU membership should be common strategic goal for all the countries in the Western Balkans. Finally, one can conclude that despite the worrisome voices and statements coming from the WB from time to time, indicating that we are facing political obstacles, tensions, and blockades, efforts should be made for them to be overcome successfully and to work hard towards realization of all the activities that will be pacing the road of the WB countries towards the EU. WB countries should strongly step along that track, concentrating on reforms and adoption of European values. Maybe it is high time for the region to rely less on the EU mediation and the WB countries to work harder together coping with challenges in the region and the European path.

\section{References:}

1. Adler, Emanuel and Michael Barnett (1998). A framework for the study of security communities. In: Emanuel Adler and Michael Barnett (eds.): Security Communities, pp. 29-65. Cambridge: Cambridge University Press. 
2. Buzan, Barry and Ole Weaver (2003).Regions and Powers. The Structure of International security. Cambridge: Cambridge University Press.

3. Deutch, Karl (1954). Political Community at the International Level: Problems of Definition and Measurement. Utah: Ardwork Global Publishing Company.

4. Ejdus, Filip (2011). Towards the Western Balkans. Security Community 2.0. Analysis. Beograd: Faculty of Political Sciences.

5. European Commission. 2003. EU-US Summit, Washington, 25 June 2003. http:// trade.ec.europa.en/doclib/docs/2003/ November/tradoc_ 114831.pdf (21.5. 2013).

6. Ghebali, Yves, Brigitte Sauerwein (1995). European Security in the 1990's: Challenges and Perspectives. Geneva: UNidIR.

7. Rupnik, Jaques (2010). Reassessing European Challenges in the Balkans. European Perspectives-Journal on European Perspectives of the Western Balkans. Vol. 2, No. 2, pp. 7-12. October 2010.

8. Minić, Jelica (2013). The dynamics and context of regional cooperation in the Western Balkans. International Issues\& Slovak foreign policy affairs, 22 (4), pp.21-39. 